\title{
SEXUAL CYCLE OF WHITE BREAM, BLICCA BJOERKNA (ACTINOPTERYGII, CYPRINIFORMES, CYPRINIDAE), FROM THREE SITES OF THE LOWER ODER RIVER (NW POLAND) DIFFERING IN TEMPERATURE REGIMES
}

\author{
Józef DOMAGAŁA, Katarzyna DZIEWULSKA, Lucyna KIRCZUK*, \\ and Małgorzata PILECKA-RAPACZ
}

Division of General Zoology, University of Szczecin, Poland

\begin{abstract}
Domagała J., Dziewulska K., Kirczuk L., Pilecka-Rapacz M. 2015. Sexual cycle of white bream, Blicca bjoerkna (Actinopterygii, Cypriniformes, Cyprinidae), from three sites of the lower Oder River (NW Poland) differing in temperature regimes. Acta Ichthyol. Piscat. 45 (3): 285-298.
\end{abstract}

\begin{abstract}
Background. One of the largest European populations of white bream, Blicca bjoerkna (Linnaeus, 1758), can be found in the estuary of the Oder River. This fish is not only very abundant in this area but also attains sizes that have no match in other areas of central Europe. In search for the clues behind such reproductive success we decided to study the annual development cycle of gonads of white bream from three sites in the lower Oder River, north-western Poland, differing in temperature regimes (depending on their position and the distance from the discharge outlet of the Dolna Odra Power Plant).

Materials and methods. White bream individuals were obtained from the three sites as bycatch of commercial fishing in 2009 and 2010. Three sites were sampled: (1) the Oder River above the power plant, (2) the warm-water canal with post-cooling water discharged from the power plant, and (3) Lake Dąbie, $20 \mathrm{~km}$ below the warm-water canal. The fish age was determined as 2+ through 9+. In total, 506 females and 190 males were designated for histological analyses. The analysis of the annual cycle of gonad development was performed in both sexes using histological methods. A standard paraffin technique and Heidenhain's iron hematoxylin staining were used.

Results. In the Oder River, spawning of white bream lasted from early May to late June. In Lake Dąbie, it extended until the beginning of July. The spawn was laid in 2 or 3 portions. In the warm-water canal spawning began one month earlier, in April. The bream males from the thermally unaffected Oder River were ready for reproduction approximately one month earlier than the females and maintained their reproductive potential similarly to the females. Males from the warm-water canal became sexually mature two months earlier (February) than those from the river above the power plant.

Conclusion. In waters with elevated temperature, gametogenesis of white bream occurs without problems and the fish exhibit a typical pace of growth depending on the temperature. In the perspective of climate warming, white bream will be able to maintain its status of a common species in the natural waters of the region.
\end{abstract}

Keywords: fish, reproductive cycle, gonad, post-cooling water, spermatogenesis, oogenesis

\section{INTRODUCTION}

One of the largest and most viable European populations of white bream, Blicca bjoerkna (Linnaeus, 1758), can be found in the estuary of the Oder River (on the Polish-German border. This fish is not only very abundant in this area but also attains sizes that have no match in other areas of central Europe. Specimens weighing $1 \mathrm{~kg}$ are not an exception while in other European bodies of water they rarely exceed $25 \mathrm{~cm}$ (FL) (Lammens et al. 1992) or $300 \mathrm{~g}$ (Specziár et al. 1997, Kopiejewska and Kozłowski 2007). In the search for the clues behind such welfare and reproductive success we decided to study the annual development cycle of gonads of white bream from three sites in the lower Oder River, north-western Poland, differing in temperature regimes. A good place for such observation was a thermal power plant Dolna Odra, situated some $100 \mathrm{~km}$ from the Baltic Sea. Thermal post-cooling effluents from the power plant affect the river temperature, but this effect diminished with the distance from the discharge outlet.

White bream, Blicca bjoerkna, is a common cyprinid species present in the waters of almost entire Europe (Tadajewska 2000) although its economic significance is rather minor. Its ubiquity, however, suggests that it is a very important component for the proper functioning of ecosystems (Kompowski and Neja 1999). White bream is a multiple spawner (Brylińska and Żbikowska 1997,

\footnotetext{
* Correspondence: dr Lucyna Kirczuk, Uniwersytet Szczeciński, Katedra Zoologii Ogólnej, ul. Felczaka 3c, 71-412 Szczecin, Poland, phone: +48 91 444-1618; fax +4891 444-1623; e-mail: (LK) lucyna.kirczuk@univ.szczecin.pl, (JD) jozef.domagala@univ.szczecin.pl, (KD) katarzyna.dziewulska@univ.szczecin.pl, (MPR) rapacz@univ.szczecin.pl
} 
Lefler et al. 2008). The available studies of the species consider its reproductive behaviour (Poncin et al. 2010), hormonal oogenesis regulation (Rinchard and Kestemont 2003), analysis of gonads from selected months (Kopiejewska and Kozłowski 2007), as well as the full-year gonad development cycle only in females, but under ambient thermal conditions (Rinchard and Kestemont 1996, Lefler et al. 2008). A broad analysis of ecological conditions favourable for the reproduction of white bream has also been conducted (Janáč et al. 2010).

The temperature of the aquatic environment is one of the most important factors affecting fish development (Brett 1979, Herzig and Winkler 1986, Jobling 2003). The water temperature also affects the characteristics associated with fish reproduction, such as sex determination, gametogenesis dynamics, gamete quality, fertility, fertilisation effectiveness, age of sexual maturity, as well as the duration of the reproductive season (Breton et al. 1980, Billard 1986, Jafri 1989, Sandström et al. 1995, Alavi and Cosson 2005, Lahnsteiner and Mansour 2012, Domagała et al. 2013). Post-cooling water discharged from power plants into natural waters increases water temperature and alters the living conditions of fish. In fish living under these conditions, accelerated gametogenesis was usually observed (Mattheeuws et al. 1981, Lukšjenè and Svedäng 1997, Lukšjenè et al. 2000). A negative effect on gonad development and abnormalities of oogenesis were observed (Luksjene and Sandström 1994, Lukšjenè and Svedäng 1997, Lukšjenė et al. 2000). Unusual changes in gonads, such as oocyte atresia in early vitellogenesis, were observed in fish inhabiting endorheic bodies of water into which post-cooling water is discharged (Lukšjenè et al. 2000). Also, in locations where post-cooling water enters open waters, spawning abnormalities were observed in such species as Perca fluviatilis Linnaeus, 1758; Rutilus rutilus (Linnaeus, 1758); and Esox lucius Linnaeus, 1758 (see Lukšjenè et al. 2000).

No studies of the effect of temperature on the sexual cycle of either sex of white bream have been performed to date. The aim of this study was to analyse the annual gonad maturation cycle of white bream in three locations differing in thermal regimes (depending on their position and the distance from the discharge outlet of the Dolna Odra Power Plant): the Oder River, the warm-water canal, and Lake Dąbie. This study was intended to elucidate the dynamics of the reproductive cycle of white bream from north-western Poland and the potential effect of elevated temperature on the cycle.

\section{MATERIAL AND METHODS}

The adult males and females of white bream, Blicca bjoerkna (Linnaeus, 1758) (Cyprinidae), from populations inhabiting three water bodies under different temperature regimes were investigated:

- The eastern branch of the Oder River, up to $20 \mathrm{~km}$ upstream from the Dolna Odra Power Plant;

- The warm-water canal, $200 \mathrm{~m}$ downstream from the post-cooling water discharge outlet of the Dolna Odra Power Plant, Nowe Czarnowo, near Gryfino, NW Poland $\left(53^{\circ} 11^{\prime} \mathrm{N}, 14^{\circ} 29^{\prime} \mathrm{E}\right)$;
- Southern part of Lake Dąbie, $20 \mathrm{~km}$ downstream from the Dolna Odra Power Plant.

The Oder River estuary extends more than $100 \mathrm{~km}$ inland from the Baltic Sea from the point where the river bifurcates forming two major branches (eastern and western) and a multitude of interconnecting canals. A shallow flow-through Lake Dąbie is located in the midway to the sea not far away from the Szczecin Lagoon, which is separated from the Baltic by two large post-glacial islands: Wolin and Usedom.

The warm-water canal of the power plant is relatively deep and fast flowing. Its mean water temperature is by $6-8^{\circ} \mathrm{C}$ higher than that of the river upstream and in the warmest months the water temperature reaches $26-30^{\circ} \mathrm{C}$ (Domagała and Kondratowicz 2005, Domagała and Pilecka-Rapacz 2007). Water temperature at the first and the third site was similar. The characteristics of the temperature in the studied period in the three locations are presented in Fig. 1.

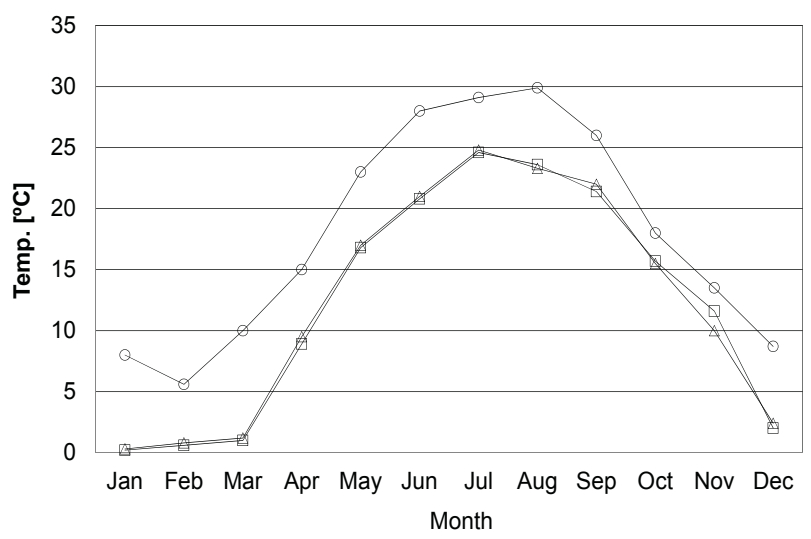

Fig. 1. Water temperature within 2009-2010 in the area studied; $\Delta=$ Oder River; $\square=$ Lake Dąbie; $\circ=$ warm-water canal; Reprinted from Journal of Applied Ichthyology (Domagała et al. 2015) with permission from John Wiley \& Sons Ltd.

White bream were caught as bycatch by commercial fishermen who used gillnets at the three aforementioned sites between September 2009 and August 2010, from one to four times a month at each site. Altogether, 506 females and 190 males were designated for histological analyses. Once numerous samples were collected, ovaries for a detailed assessment of maturation stage based on the value of the gonadosomatic index (GSI) were selected (Table 1). The fish age was determined as $2+$ through $9+$ based on the analysis of rings on the collected scales. The total length (TL) and standard length (SL) of each fish specimen were measured to the nearest $1 \mathrm{~mm}$ and each fish was weighed on an electronic scale to the nearest $0.1 \mathrm{~g}$. Then, the gonads were dissected, fixed in Bouin fluid, and weighed to the nearest $0.1 \mathrm{mg}$. Two parameters were calculated: the Fulton condition factor $(K)$ and the gonadosomatic index (GSI) using the respective formulas:

$$
K=100 W_{\mathrm{g}} \cdot \mathrm{TL}^{-3}
$$


and

$$
\mathrm{GSI}=100 W_{\mathrm{g}} \cdot W_{\mathrm{b}}^{-1}
$$

where: TL is the total length of fish [cm], $W_{\mathrm{g}}$ is the gonad weight [g], and $W_{\mathrm{b}}$ is the total fish weight [g].

For histological analysis gonad fragments $0.5 \mathrm{~cm}$ in length were cut out from the middle part of the gonad and processed using a standard paraffin technique. Between 50 and 100 sections were made from each gonad. Five- $\mu \mathrm{m}-$ thick sections were regressively stained with Heidenhain's iron hematoxylin. The histological slides were analysed and measured under a light microscope Nikon Eclipse 80i and photographic documentation was made using the program NIS Elements 3.20 and a digital camera Nikon DS$5 \mathrm{Mc}-\mathrm{U} 2$, of $5 \mathrm{mln}$ pixel resolution.

There were three principal reasons for

DOIng histological evaluation of female gonads of white bream:

- Determining their maturity-6 degree scale applied in Sakun and Buckaâ (1963);

- Determining the size of oocytes in particular stages of development and in individual months;

- Identifying the number of degenerating oocytes.

The following histological measurements were made:

- The most developed oocytes from the most developed gonads in a given month ( 5 females from each site, 30 oocytes measured from one gonad);

- Oocytes from each stage of development from all sites (10 gonads representing each stage, 30 oocytes measured from one gonad);

- Oocyte size at vitellogenesis in the stage of vacuolisation, yolk accumulation and completion of vitellogenesis.

The guidelines provided by Wallace and Selman (1981) were used for oocyte identification. The measurements were made to the nearest $0.01 \mu \mathrm{m}$. The oocyte diameter was calculated from measurements of the longest and shortest diameters of the mid cross sections of the oocyte (Hunter and Goldberg 1980).

The sexual cycle of males was described using modified 6-stage scale proposed by Sakun and Buckaâ (1963). The division into early and late substages of the stages II ( $\mathrm{II}_{\mathrm{E}}$ and $\mathrm{II}_{\mathrm{L}}$ ) and III ( $\mathrm{III}_{\mathrm{E}}$ and $\mathrm{III}_{\mathrm{L}}$ ) was introduced, as well as overlapping of the gonadal cycles designated as substages VI-I and VI-II.
- Stage I: type A spermatogonia occurring in seminiferous tubules; small amounts of residual spermatozoa from the previous cycle can also be found;

- Stage II: cysts with type B spermatogonia occurring in seminiferous tubules; small amounts of residual spermatozoa from the previous cycle can also be found;

- $\mathrm{II}_{\mathrm{E}}$ : early stage; the seminiferous tubules are filled with type A spermatogonia; few cysts with type B spermatogonia are formed, with up to approx. 10 cells visible in the cross-sections of the cyst

- $\mathrm{II}_{\mathrm{L}}$ : late stage; the seminiferous tubules contain numerous cysts with more than 10 type B spermatogonia in the cyst;

- Stage III: primary spermatocytes and consecutive cells of the spermatogenesis appearing in seminiferous tubules; the first spermatozoa can be found, efferent duct without spermatozoa;

- $\mathrm{III}_{\mathrm{E}}$ : early stage; the seminiferous tubules contain cysts with type B spermatogonia and primary spermatocytes;

- III $_{\mathrm{L}}$ : late stage; the seminiferous tubules contain numerous cysts with all types of spermatogenic cells from spermatogonia type A to spermatozoa; the efferent duct without spermatozoa;

- Stage IV: seminiferous tubules contain cells at all spermatogenetic stages (from type A spermatogonia to spermatozoa); the tubule lumen and the efferent duct filled with numerous spermatozoa;

- Stage V: gonad with finalized spermatogenesis; the seminiferous tubules are filled with numerous spermatozoa; no younger spermatogenic cells or scarce cysts with younger spermatogenic cells have been observed; the efferent duct filled with milt;

- Stage VI: spent gonads, seminiferous tubules containing small number of residual spermatozoa, efferent duct may contain spermatozoa;

- Stage VI-I: only type A spermatogonia occurring in tubule wall;

- Stage VI-II: type A spermatogonia and cysts with type B spermatogonia start forming adjacent to the tubule wall Statistical analysis. The nonparametric Kruskal-Wallis test and following multiple comparisons were used to compare the characteristics of the fish: body length and weight, condition coefficient $(K)$, gonadosomatic index (GSI), and oocyte size. All analyses were performed at the significance level of 0.05 using the Statistica v. 10 software (StatSoft, Inc.).

Table 1

Number of individuals of white bream, Blicca bjoerkna, used in the histological study

\begin{tabular}{|c|c|c|c|c|c|c|c|c|c|c|c|c|c|c|}
\hline \multirow{2}{*}{ Sampling site } & \multirow{2}{*}{ Sex } & \multicolumn{12}{|c|}{ Number of fish per month } & \multirow{2}{*}{ Total } \\
\hline & & Jan & Feb & Mar & Apr & May & Jun & Jul & Aug & Sep & Oct & Nov & Dec & \\
\hline \multirow[t]{2}{*}{ Oder River } & q & 18 & 13 & 20 & 22 & 30 & 13 & 33 & 9 & 20 & 17 & 11 & 21 & 205 \\
\hline & $\hat{\delta}$ & 1 & 2 & 2 & 22 & 15 & 3 & 5 & 1 & 1 & 2 & 2 & 2 & 58 \\
\hline \multirow[t]{2}{*}{ Lake Dąbie } & q & 8 & 10 & 17 & 21 & 25 & 15 & 11 & 9 & 8 & 25 & 16 & 22 & 187 \\
\hline & $\hat{0}$ & 3 & 2 & 2 & 25 & 40 & 20 & 3 & 1 & 1 & 10 & 2 & 3 & 112 \\
\hline \multirow[t]{2}{*}{ Warm-water canal } & 웅 & 4 & 12 & 35 & 8 & 10 & & & 6 & 17 & 9 & 4 & 9 & 114 \\
\hline & $\hat{\sigma}$ & 2 & 2 & 4 & & 5 & & & 4 & 1 & 1 & & & 19 \\
\hline
\end{tabular}




\section{RESULTS}

Principal somatic parameters of fish. The caught fish were at the age of 2 and above. The number of the sampled white bream males was much lower than that of the females. In some months, only single individuals were caught (Table 1). The length, weight, and condition factor of the studied white bream differed significantly between sexes (KruskalWallis test, $H=134.4$, df $=5, P<0.05 ; H=166.4$, df $=$ 5; $P<0.05$, and $H=148.4$, df $=5, P<0.05$, respectively). Body length and weight of the females caught at individual sites were significantly higher than those of the males collected at the same sites $(P<0.05)$. The length, weight, and condition factor of the females from three locations studied did not differ significantly $(P>0.05)$. Also in the males caught in the three locations, these features did not show statistically significant differences between samples $(P>0.05)$. The condition factor of the males from natural waters was lower than that of females $(P<0.05)$, while the $K$ value of the males from the warm-water canal was similar in both sexes of the fish caught in other studied locations $(P>0.05)$ (Table 2).

The smallest maturing female was $14.3 \mathrm{~cm}$ long (SL) and was caught in Lake Dąbie. In March and April, also single large females, 30-34 cm in length, with gonads which would not mature in that season were caught in this location. The males that underwent sexual maturation in the three investigated bodies of water were longer than $8.5 \mathrm{~cm}$. In parallel, in the two investigated natural habitats there were males with body sizes of $23-28 \mathrm{~cm}$ that did not undergo sexual maturation in the investigated reproductive season. Variation of GSI in females. In each month of spawning, gonads were divided into 2 groups. One group were pre-spawning gonads, while the other group were spawning gonads. The highest GSI values in the investigated white bream were observed in the spring. Mean monthly values are presented in a chart (Fig. 2A). However, if fish in each location are divided according to the preparation for spawning from April to June, the females belong to one of two groups: the group with pre-spawning and spawning gonads and the group with post-spawning gonads, which is reflected in the GSI values. The average GSI values (mean \pm standard deviation) in the group of females from the Oder River with pre-spawning gonads in April, May, and June were $12.79 \pm 4.27,15.86 \pm 2.70$, and $13.44 \pm 1.31$, respectively, while in the post-spawning group, the values in May and June were $4.66 \pm 1.26$ and $2.31 \pm 2.47$, respectively. GSI of the pre-spawning group from Lake Dąbie in these months was $11.88 \pm 4.68$, $14.32 \pm 1.26$, and $8.85 \pm 1.87$ respectively, whereas GSI in the post-spawning group was $4.66 \pm 1.61$ and $2.63 \pm$ 1.26 , respectively. GSI of the white bream caught in the warm-water canal in April and May just before spawning was $9.63 \pm 1.20$ and $18.25 \pm 1.25$, respectively, while GSI after spawning was $0.89 \pm 0.50$ and $0.75 \pm 0.89$, respectively. The highest GSI value of 23.0 was observed in single females caught in May in the Oder River and Lake Dąbie. GSI was the lowest in July, as gonads in all females were in the post-spawning state, and the mean values in the white bream from the Oder River and Lake Dąbie were $1.20 \pm 0.78$ and $1.19 \pm 0.73$, respectively. In the subsequent months, GSI gradually increased and a pronounced increase in its value occurred in the white bream from all sites between August and November, with the highest values just before spawning (March-May).

Variation of GSI in males. During the year, gonad weight and the gonadosomatic index fluctuated along with the sexual cycle (annual changes in GSI are shown in Fig. 2B). The high GSI values were observed in white bream from the Oder River and Lake Dąbie in April. Mean GSI in the individuals from the Oder finalizing their spermatogenesis (stages III $_{\mathrm{L}}$ to $\mathrm{V}$ ) in that month was $7.18 \pm 1.53$ (mean \pm standard deviation), ranging from 2.59 to 9.03 , while for individuals caught in Lake Dąbie in that month, the mean index was $5.26 \pm 1.88$, ranging from 1.5 to 8.4. In April, in addition to the individuals finalizing their spermatogenesis, individuals at stage $\mathrm{I}_{,} \mathrm{II}_{\mathrm{L}}$, and $\mathrm{III}_{\mathrm{E}}$ were caught. In the warm-water canal, mature male gonads at stage IV were found as early as in February, with GSI of 7.98 in this particular male. In May and June individuals ready for spawning in natural waters have a lower value of GSI than in April. A large reduction in the values of the parameter was reported in the Oder population in July (mean GSI $=0.35 \pm 0.36$ ), with individuals at stage $\mathrm{II}_{\mathrm{E}}$ characterized by GSI of 0.76 \pm 0.18 and stage I of $0.08 \pm 0.05$. From September, gonad weight and the GSI values slowly increased until the following spring, i.e., the next reproductive season (Fig. 2B).

Table 2

Characteristics of the examined white bream, Blicca bjoerkna from three sites in the lower Oder River

\begin{tabular}{|c|c|c|c|c|c|c|c|c|c|c|}
\hline \multirow{2}{*}{ Sex } & \multirow{2}{*}{ Site } & \multirow{2}{*}{$n$} & \multicolumn{2}{|c|}{ Total length [cm] } & \multicolumn{2}{|c|}{ Standard length $[\mathrm{cm}]$} & \multicolumn{2}{|c|}{ Fish weight $[\mathrm{g}]$} & \multicolumn{2}{|c|}{ Fulton condition factor } \\
\hline & & & Mean \pm SD & Range & Mean \pm SD & Range & Mean \pm SD & Range & Mean \pm SD & Range \\
\hline \multirow{3}{*}{ 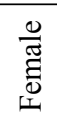 } & Oder & 205 & $29.88 \pm 3.50^{\mathrm{a}}$ & $22.0-40.0$ & $24.42 \pm 3.23^{\mathrm{a}}$ & $17.8-36.5$ & $405.46 \pm 145.64^{\mathrm{a}}$ & $125.5-817.9$ & $1.43 \pm 0.24^{\mathrm{a}}$ & $0.57-2.73$ \\
\hline & Dąbie & 187 & $29.02 \pm 4.9^{\mathrm{a}}$ & $14.3-42.0$ & $24.06 \pm 3.42^{\mathrm{a}}$ & $12.6-34.4$ & $395.34 \pm 159.92^{\mathrm{a}}$ & $78.3-971.4$ & $1.43 \pm 0.19^{\mathrm{a}}$ & $0.73-2.88$ \\
\hline & WWC & 132 & $28.33 \pm 3.23^{\mathrm{a}}$ & $15.5-37.9$ & $23.14 \pm 3.33^{\mathrm{a}}$ & $14.5-31.4$ & $339.95 \pm 151.67^{\mathrm{a}}$ & $32.3-733.1$ & $1.38 \pm 0.18^{\mathrm{a}}$ & $0.94-2.41$ \\
\hline \multirow{3}{*}{$\frac{\frac{0}{\pi}}{\sum}$} & Oder & 58 & $25.61 \pm 4.43^{\mathrm{b}}$ & $15.1-37.2$ & $21.44 \pm 3.21^{\mathrm{b}}$ & $13.1-28.9$ & $237.82 \pm 133.50^{b}$ & $33.4-663.8$ & $1.27 \pm 0.18^{\mathrm{b}}$ & $0.71-1.63$ \\
\hline & Dąbie & 112 & $24.84 \pm 6.00^{\mathrm{b}}$ & $11.6-41.5$ & $20.00 \pm 5.19^{b}$ & $8.5-33.6$ & $217.79 \pm 160.69^{b}$ & $17.0-844.8$ & $1.20 \pm 0.12^{\mathrm{b}}$ & $0.91-1.47$ \\
\hline & WWC & 19 & $21.88 \pm 5.85^{\mathrm{b}}$ & $9.7-32.0$ & $17.38 \pm 5.00^{\mathrm{b}}$ & $7.8-26.4$ & $179.74 \pm 134.98^{b}$ & $8.2-399.8$ & $1.32 \pm 0.25^{\mathrm{ab}}$ & $0.90-1.82$ \\
\hline
\end{tabular}

Oder $=$ Oder River, Dąbie $=$ Lake Dąbie, $\mathrm{WWC}=$ warm-water canal, $\mathrm{SD}=$ standard deviation; Values marked with different superscript letters show significant differences between the features $(P<0.05$, ANOVA Kruskal-Wallis test). 
A

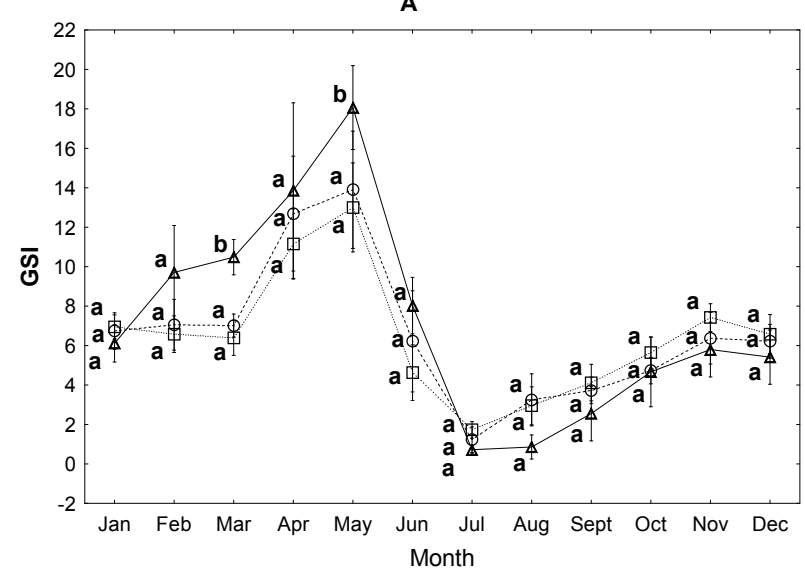

B

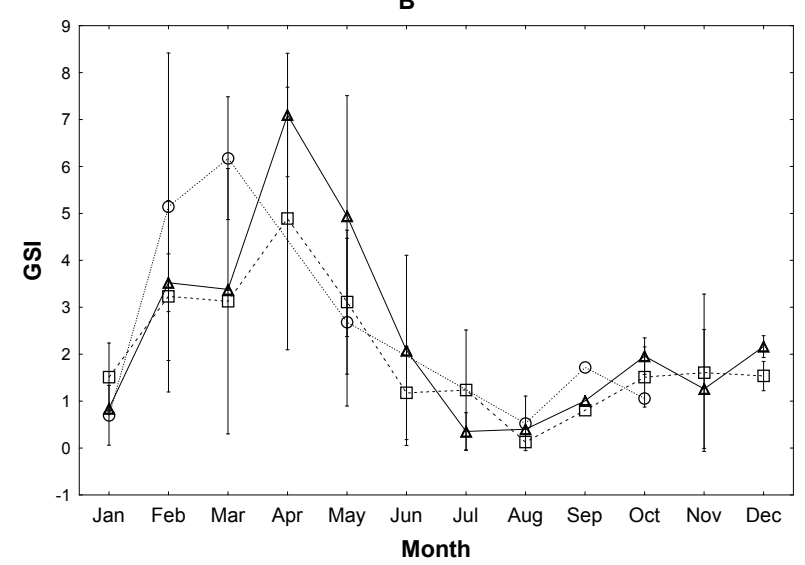

Fig. 2. Monthly distribution of Gonadosomatic Index (GSI) of white bream, Blicca bjoerkna; Females (A); and males (B) from the study areas: $\Delta$ Odra River; 口 Lake Dąbie; o warm-water canal; Values marked with different letters $(a, b)$ show significant differences between the features in the study area in a particular month $(P<0.05$, ANOVA Kruskal-Wallis test); Due to the low number of males caught, the statistic was not performed for that sex; mean $\pm \mathrm{SD}$

Reproductive cycle of females-Oder River. In mid July, white bream females had post-spawning gonads with regenerating oocytes at stage II and III (onset of vitellogenesis). The gonads contained degenerating oocytes from the previous pool that had not been laid in the spawning season (Fig. 3A). In August, all gonads were at stage III, with multiple lipid droplets. In September, gonads also contained oocytes at stage III, but these were larger than the oocytes from the preceding month. In the gonads from August and September, still present were degenerating oocytes not released during spawning (Fig. 3B). In October, the majority of females had gonads with stage IV oocytes. However, the remaining females caught in that month still had gonads at stage III. Between November and March, all females had gonads at stage IV. In these gonads, among the more mature vitellogenic oocytes were dispersed oocytes in previtellogenesis (Fig. 3C). In midApril, egg yolk deposition in oocytes and the finalization of vitellogenesis occurred. In the first days of May, mi- gration of the nuclei toward the poles of oocytes, which reached their maximum size, i.e., stage $\mathrm{V}$, was observed. Also, in early May, degenerating oocytes (Fig. 3D) were observed in post-spawning gonads filled with another portion of stage III oocytes in advanced vitellogenesis (Fig. 3E). Stage $V$ was observed in white bream females until mid-June. In the second half of that month, all white bream caught had post-spawning gonads characterized by the atresia of oocytes that had not been laid during spawning. In these gonads, oocytes at stage III that could possibly still mature in the same season and be laid in a subsequent portion were present (Fig. 3F). Spawning of the white bream from that location occurred in portions, with the beginning in the first half of May and the end in late June.

Detailed percentage of females with gonads at each maturity stage is shown in Fig. 4A.

Reproductive cycle of females-Lake Dąbie. In early July, the gonads of some white bream females contained oocytes in advanced vitellogenesis just before laying. Other females probably had already deposited their last portion of eggs. Their gonads contained envelopes of laid oocytes, degenerating oocytes not laid during spawning, as well as the next pool of oocytes at stage II or early stage III (single lipid droplets). Females caught in mid-July had gonads with degenerating post-spawning oocytes, probably constituting the last portion, as other oocytes were in stage II and would not mature in that season. In late July, females whose gonads contained mature oocytes were caught, some of which was in the process of degeneration. These females probably did not manage to depose the final portion of eggs. At the end of that month, females with gonads containing stage III oocytes and degenerating post-spawning oocytes were also caught. From September to July, the gonads of females from that location had a similar appearance as the gonads of the females from the Oder River. The spawning of white bream in this location ended one month later than in the Oder River and was divided into at least 2 clearly distinguishable portions.

Some gonads developed asynchronously: apart from oocytes in vitellogenesis, approx. 50\% of gonad section was occupied by oocytes in previtellogenesis and at the onset of vitellogenesis.

Detailed percentage of females with gonads at each maturity stage is shown in Fig. 4B.

Reproductive cycle of females-warm-water canal. In August, females with stage II gonads containing degenerating oocytes not laid during spawning were caught. In September, all gonads were at stage III and contained open envelopes, the remainder of the deposed oocytes. Between October and March, gonads were at stage IV. In the gonads of one female caught in February, 1/3 of its gonad section consisted of degenerated oocytes, while the remaining part consisted of stage IV oocytes. In April, most females had gonads with oocytes in vitellogenesis, but in single females, additional groups of oocytes in previtellogenesis could be observed. At the beginning of May, the females had gonads in advanced vitellogenesis 


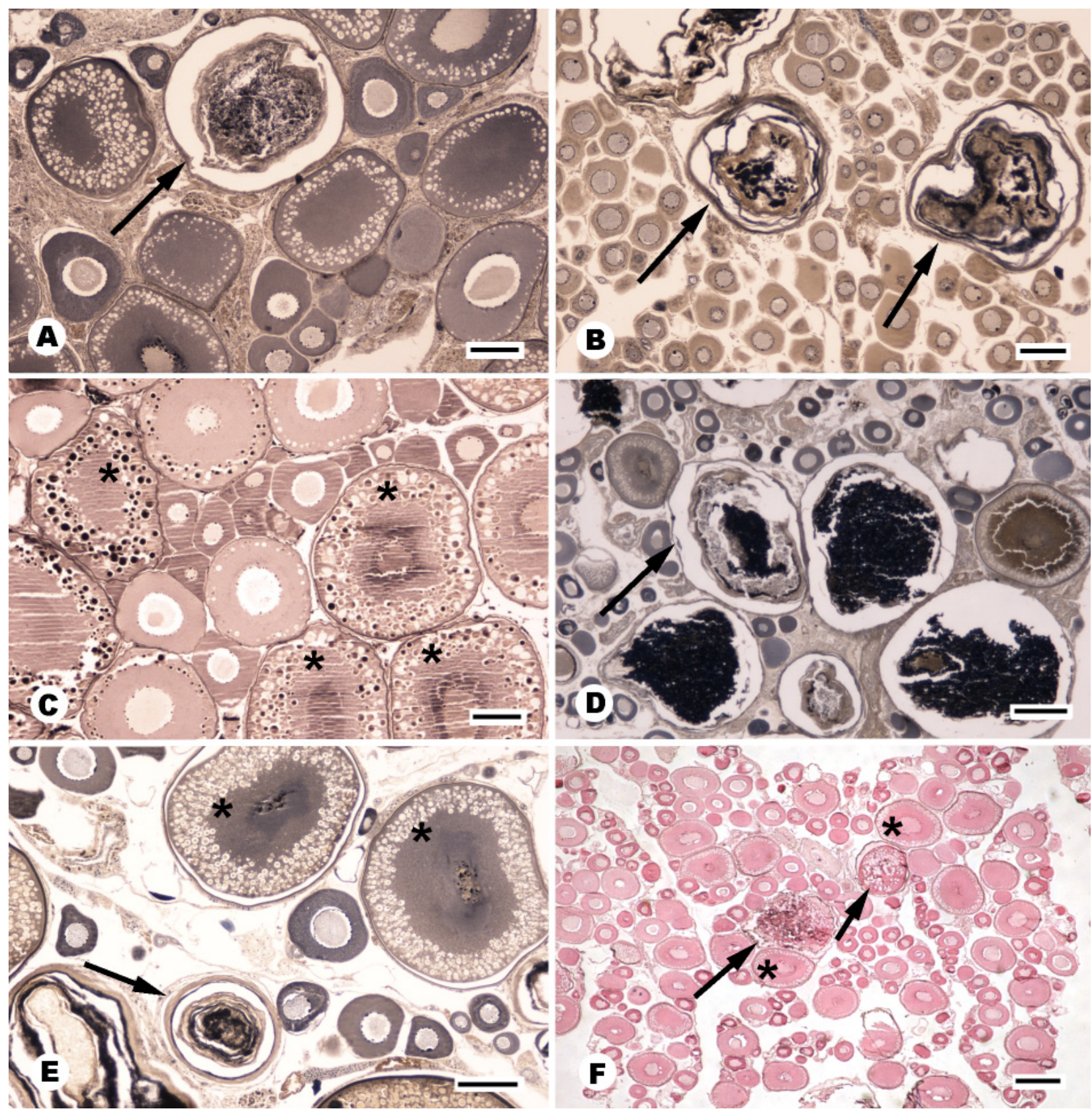

Fig. 3. Gonad of a female white bream, Blicca bjoerkna, after spawning with numerous degenerated oocytes (arrows); A: July; B: September; C: asynchronous development of the gonads, with oocytes in vitellogenesis (V) and in previtellogenesis (P), October; D: with numerous degenerated oocytes (arrows), early May; E: after spawning, with degenerated oocytes (arrows), second half of May; F: with numerous degenerated oocytes, December; Scale bar: 200 $\mu \mathrm{m}$ in all images

and post-spawning gonads. Therefore, spawning in this body of water could take place at the beginning of April. White bream specimens with post-spawning gonads containing multiple oocytes in vitellogenesis (the following portion) were caught in a small shallow, separated gulf, where the conditions were appropriate for spawning. Other white bream specimens, due to strong water current in the middle part of the Canal, probably moved below the Canal for spawning. Based on the collected material, we may assume that two portions of eggs were deposited in the warm-water canal, the first portion in April and the second portion in early May. In June and July, no mature white bream females were caught in this body of water and therefore it is difficult to determine the date of the completion of spawning. Detailed percentage of females with gonads at each maturity stage during the calendar year is shown in Fig. 4C.

Reproductive cycle of females-oocyte size. The white bream females from the warm-water canal had the smallest oocytes during gonad recovery after spawning (Table 3). The females from this location also had the largest oocytes at the end of vitellogenesis compared to those from the other two sites (Fig. 5). 

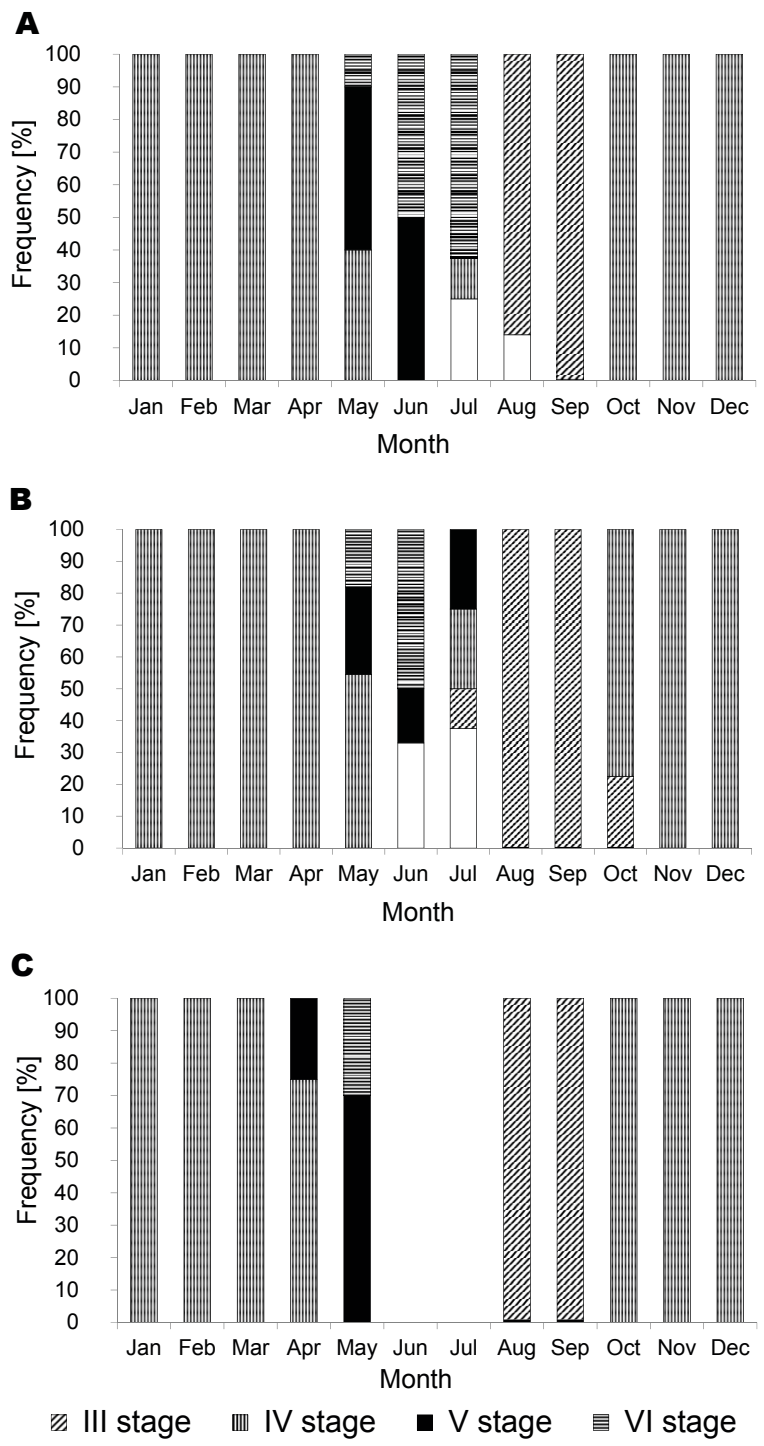

Fig. 4. Percentage contribution of the number of white bream, Blicca bjoerkna, females with gonads at particular stage of maturity in individual months of the calendar year from the three aquatic environments: Oder River (A), Lake Dąbie (B), warm-water canal (C)

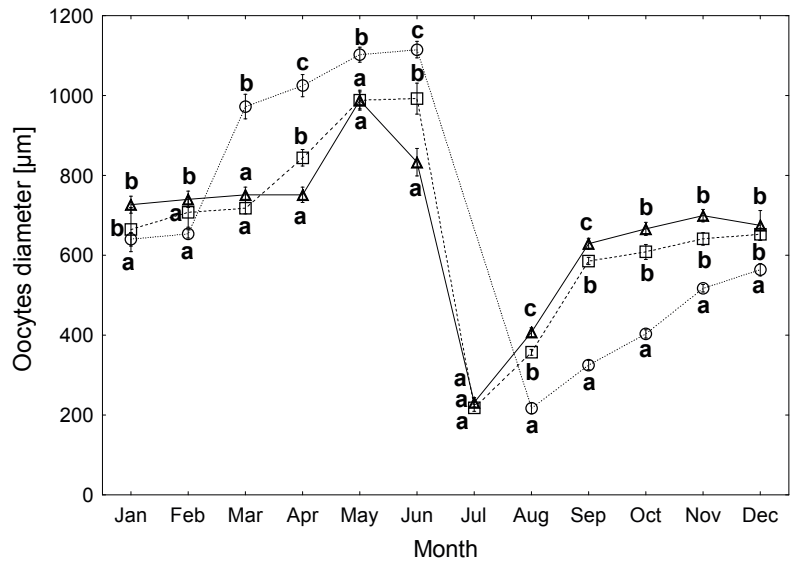

Fig. 5. Monthly distribution of the diameter of the most developed oocytes of white bream, Blicca bjoerkna, from the study areas: $\Delta$ Oder River; $\square$ Lake Dąbie; o warm-water canal; Values marked with different letters $(a, b, c)$ shows significant differences between the features in study area in a particular month $(P<0.05$, ANOVA Kruskal-Wallis test $)$; mean \pm SD

Reproductive cycle of males-Oder River. In the lower Oder River, the investigated white bream males remained ready for reproduction from mid-April to the late June. The highest percentage of males ready for spawning was observed in May. After spawning, in July, male gonads were at stage I (Fig. 6A) or early stage II. In the latter case, the formation of cysts with type B spermatogonia began in tubules. The cyst contained up to 10 cells. In the following months, from August to January, the gonads of all caught males reached substage $\mathrm{II}_{\mathrm{L}}$ (Fig. 6B). In the autumn and winter, the number of type $\mathrm{B}$ spermatogonia in cysts increased from 20-30 cells observed in cyst cross-sections in August to 50 in January. Sporadically, individuals remaining at stage I were recorded. In February, some individuals reached early stage $\mathrm{III}_{\mathrm{E}}$. In the testes of these males, primary spermatocytes appeared. In the gonads of other males, no initiation of meiosis by germ cells was observed and the gonads were at stage $\mathrm{II}_{\mathrm{L}}$. In March, the histological im-

Table 3

Oocyte size at different stages of vitellogenesis in white bream, Blicca bjoerkna, from three sites in the lower Oder River

\begin{tabular}{|c|c|c|c|c|c|c|}
\hline \multirow{3}{*}{ Stage } & \multicolumn{6}{|c|}{ Sampling site } \\
\hline & \multicolumn{2}{|c|}{ Oder River } & \multicolumn{2}{|c|}{ Lake Dąbie } & \multicolumn{2}{|c|}{ Warm-water canal } \\
\hline & Mean \pm SD & Range & Mean \pm SD & Range & Mean \pm SD & Range \\
\hline Previtellogenesis & $200.81 \pm 27.885^{\mathrm{a}}$ & $151.28-256.05$ & $218.13 \pm 26.70^{b}$ & $165.08-278.48$ & $201.39 \pm 21.25^{\mathrm{a}}$ & $152.48-277.78$ \\
\hline Vacuolisation & $223.33 \pm 30.09^{\mathrm{a}}$ & $176.24-273.94$ & $289.00 \pm 28.26^{\mathrm{ab}}$ & $251.48-350.35$ & $210.26 \pm 22.33^{b}$ & $167.23-270.34$ \\
\hline Maximum fill & $406.96 \pm 30.09^{\mathrm{a}}$ & $345.30-492.13$ & $418.78 \pm 48.83^{\mathrm{a}}$ & $296.40-507.27$ & $325.16 \pm 40.81^{\mathrm{a}}$ & $252.14-405.73$ \\
\hline Yolk & $424.76 \pm 49.87^{\mathrm{a}}$ & $335.14-511.80$ & $496.55 \pm 24.54^{c}$ & $455.51-529.39$ & $441.39 \pm 26.005^{\mathrm{b}}$ & $389.95-494.92$ \\
\hline Vitellogenesis & $987.92 \pm 42.87^{\mathrm{a}}$ & $899.34-1057.21$ & $1115.01 \pm 58.36^{\mathrm{a}}$ & $966.61-1231.84$ & $1102.23 \pm 53.86^{\mathrm{b}}$ & $915.44-1186.39$ \\
\hline
\end{tabular}

Stages: Vacuolisation = beginning of vacuolisation, Maximum fill = maximum fill level oil drops, Yolk = first occurrence of the yolk, Vitellogenesis = vitellogenesis completed; Values marked with different superscript letters show significant differences between the features $(P<0.05$, ANOVA Kruskal-Wallis test). 
age of the gonads was similar as in the preceding month. In April, individuals at very different stages of maturity, from stage $\mathrm{II}_{\mathrm{L}}$ to stage $\mathrm{V}$, were observed. In the individuals at stage $\mathrm{III}_{\mathrm{L}}$, the first spermatozoa appeared (Fig. 6C). At stage IV, spermatozoa filled both the lumen of the seminiferous tubules and the efferent ducts, while less developed cells underwent maturation in (still) numerous cysts at the tubule wall (Fig. 6D). In the individuals at stage $\mathrm{V}$ of maturity, spermatogenesis in the seminiferous tubules was almost completed and the lumen of the tubules was filled with spermatozoa (Fig. 6E). In May, maturing individuals were at stage IV or V. In that month, the highest percentage of males ready for spawning was recorded, but there were also few individuals at substage $\mathrm{II}_{\mathrm{E}}$. In June, one-third of males were still ready for reproduction (stage $\mathrm{V}$ ), while the remaining males were at stage $\mathrm{I}$ or $\mathrm{II}_{\mathrm{L}}$. A small quantity of spermatozoa from the late reproductive season was found in one individual. In July, gonads containing spermatozoa were no longer observed, and the males were at stage I and early stage $\mathrm{II}_{\mathrm{E}}$. Detailed percentages of males with gonads at each maturity stage during the calendar year are shown in Fig. 7A.

Reproductive cycle of males - Lake Dąbie. Similarly as the males from the Oder River, those caught in Lake Dąbie remained ready for reproduction in the same period, i.e., from early April through late June. In May, this site was characterized by the highest percentage of males with spawning gonads (stage IV and V). However, this site was also characterized by a slightly earlier (in February) occurrence of the first spermatozoa in gonads (stage III $_{L}$ ) than in the river above the power plant. Individuals at stage IV were recorded at this site as late as in June. In the white bream specimens from Lake Dąbie, the dynamics of gonad recovery after spawning was similar to that of the white bream specimens from the Oder River. Post-spawning gonads were observed occasionally (stage VI-II) (Fig. 6F), while the unreleased remaining spermatozoa from the completed cycle were present only in very small quantities until the end of December. The post-spawning substage VI-II was found in only one individual from this site in June. In this month, gonads at substage $\mathrm{II}_{\mathrm{E}}$ or stage I were also found. Detailed percentages of males with gonads at each maturity stage during the calendar year are shown in Fig. 7B.

Reproductive cycle of males-warm-water canal. The study material from that location was obtained with difficulty. At this site, single males with spawning gonads (stage IV) were recorded as early as in February, two months earlier than in the waters supplying the Canal and Lake Dąbie. In the subsequent months, individuals at stages IV and $\mathrm{V}$ of gonad development were also caught. In June and July, no white bream males were caught at this site. After the reproductive season, the level of development of gonads in the white bream from the Canal corresponded to stages $\mathrm{I}_{\text {and }} \mathrm{II}_{\mathrm{L}}$. Detailed percentages of males with gonads at each maturity stage during the calendar year are shown in Fig. 7C.

\section{DISCUSSION}

White bream, along with common roach and common bream, constitutes the most significant group of freshwater fishes in the central part of Europe (Tadajewska et al. 1997, Molls 1999, Tátrai et al. 2003, Matondo et al. 2007, Wiśniewolski et al. 2009). Cyprinids, including white bream, are a flexible group that adapts well to eutrophic conditions (Persson et al. 1991, Lammens et al. 1992, Olin 2009), although they tend to avoid acidified waters (Leuven et al. 1987). They are characterized by a high fertility and flexibility of reproduction (Barthelmes 1983). In the investigated sites, more females than males were caught, therefore the results for males were based on a lower number of specimens. In other locations, females also quantitatively dominated over males, with a female-to-male ratio of $1: 0.35$ in Lake Kuş (Balık et al. 1999 — cited after Y1lmaz et al. 2012), and $1: 0.53$ in Lake Sapanca (Hamalosmanoğlu 2003 — cited after Y1lmaz et al. 2012), although other authors recorded more equal proportions of the sexes: $1: 1.07$ in Lake Sapanca (Gürsoy unpublished*) and $1: 0.98$ in Ladik Lake (Y1lmaz et al. 2012, 2015).

The white bream specimens we analysed were in a good condition, similar to those caught in other locations (Okgerman et al. 2012, Yilmaz et al. 2012). The females in the study were larger and heavier than the males, similarly as in other studies (Okgerman et al. 2012).

White bream in Poland reaches its sexual maturity at the age of 2 to 7 years and the length of 5.5 to $20.2 \mathrm{~cm}$ (Tadajewska 2000). According to other authors, mature individuals are aged $3+(14.7 \mathrm{~cm})$ or $4+(18.6 \mathrm{~cm})($ Koli 1990, Okgerman et al. 2012). Some males become mature as early as at the age of 2, while females at the age of 3-5 (Okgerman et al. 2012). The smallest maturing males we caught were $8.5 \mathrm{~cm}$ long (SL) (age 2+), while females with mature gonads were aged $3+$ and $10 \mathrm{~cm}$ long. In the two investigated natural habitats, there were males with body sizes of $23-28 \mathrm{~cm}$ that did not undergo sexual maturation in the investigated reproductive season.

The breeding season of white bream is extended in time, since the eggs are laid several times, in 2 or even 3 portions (Tadajewska 2000). However, Kopiejewska and Kozłowski (2007) concluded that some white bream females have an undetermined type of reproduction with one or several portions of eggs laid. The egg laying lasts from 35 to 75 days (Kopiejewska 1996) and from 21 to 52 day by Spivak (1987). According to Mann et al. (1984), the number of portions of laid eggs depends on the abundance of fish in a given body of water and on geographic latitude.

Spawning period in the majority of the analysed white bream specimens from the natural waters of the Oder River and Lake Dąbie was similar, although slightly longer in Lake Dąbie and it lasted from early May to late June or even early July. Ovaries with ripe oocytes were seen as late as in July, although these were single cases. In other locations in Europe: northern Russia (Berg 1949),

* Gürsoy Ç. 2001. Sapanca Gölu’nde Tahta (Blicca bjoerkna L. 1758) ve Eðrez (Vimba vimba L. 1758) Balýklarýnýn Epeysel Olgunluða Eripme Büyüklükleri ve Yumurta Verimlilikleri. [Size at maturity and fecundity of white bream (Blicca bjoerkna L. 1758) and Baltic vimba (Vimba vimba L. 1758) fish populations in Lake Sapanca.] MSc Thesis, Istanbul University, Istanbul. [In Turkish.] 

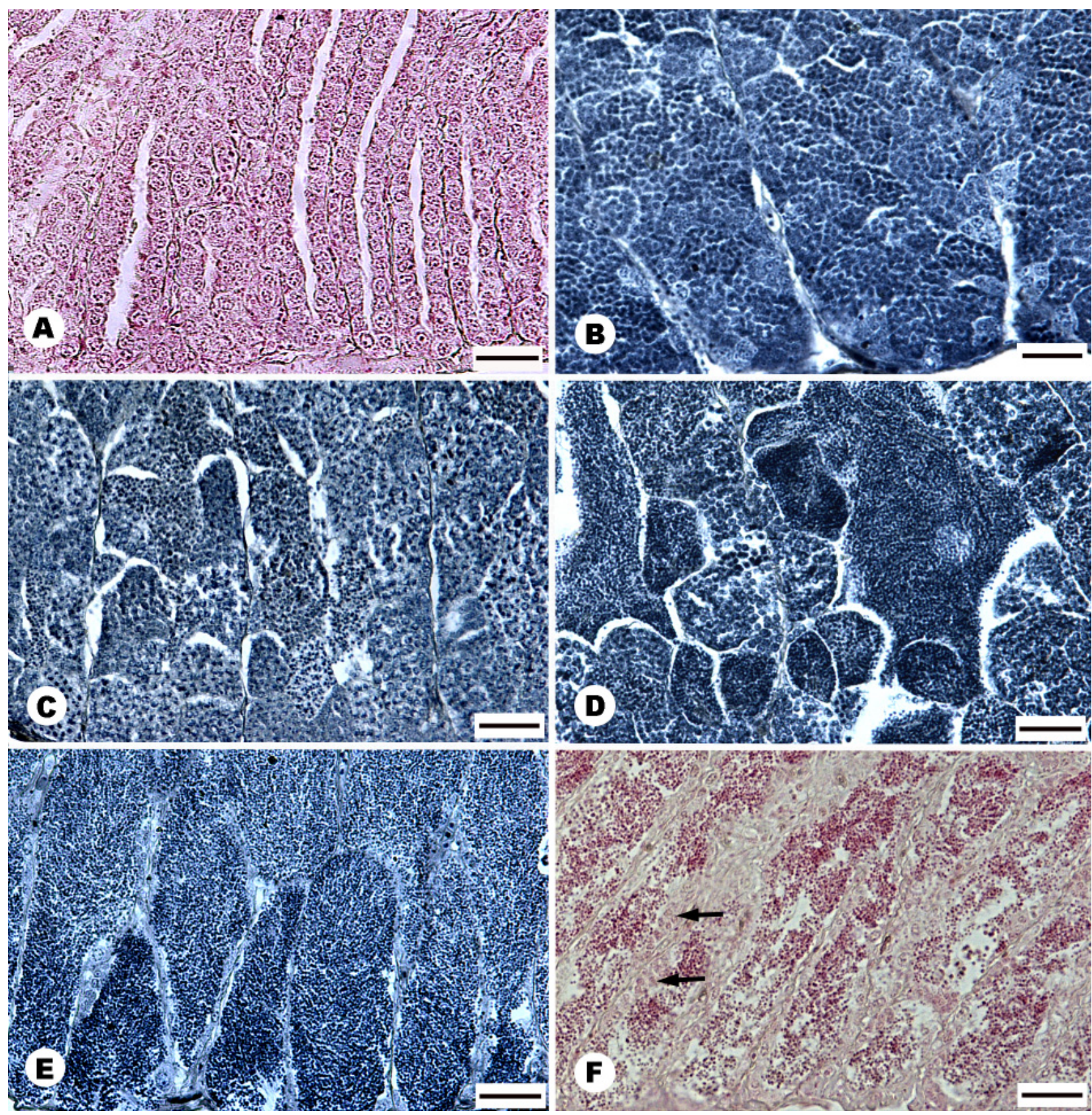

Fig. 6. Male gonad of white bream, Blicca bjoerkna; A: A white bream male gonad at stage I of maturation, by the tubule wall type A spermatogonia occurred, July; B: A gonad at late stage II, the tubules contain numerous cysts with multiplying type B spermatogonia, October; C: A gonad at late stage III, all types of spermatogenic cells are visible in the gonad, April; D: Spawning stage IV, the tubule lumen is filled with spermatozoa, by the tubule wall numerous cysts with maturing cell occurred, April; E: Spawning stage V, a gonad with finalized spermatogenesis, tubules filled with spermatozoa, the tubule wall contains only resting type spermatogonia A, May; F: A spent gonad at stage VI-II; Shrunken tubules filled with unexpelled spermatozoa; The tubule wall contains type A spermatogonia and cysts with type B spermatogonia (arrow), June; Scale bar: $50 \mu \mathrm{m}$ in all images

Belgium (Rinchard and Kestemont 1996, 2003), Germany (Spratte and Hartmann 1997, Molls 1999), spawning usually occurs in a similar period: begins in May and ends in June. The earliest spawning period was observed in Turkey in mid-April, in Lake Kuş (Balık et al. 1999_cited after Y1lmaz et al. 2012, 2015) and late April in Lake Sapanca (Okgerman et al. 2012). Spawning occurring only in May was reported in Russia (Slastenenko 1956 - cited after Y1lmaz et al. 2012) and Austria (Hacker 1979), while the latest ending date, July, was observed in Finland (Koli et al. 1990) and Turkey (Okgerman et al. 2012).

In the investigated white bream, early vitellogenesis took place in August and from that month, a steady advance of gonad recovery was observed, similarly as in the white bream from Hungary (Lefler 2010) and in some white bream from the Meuse River (Rinchard and 


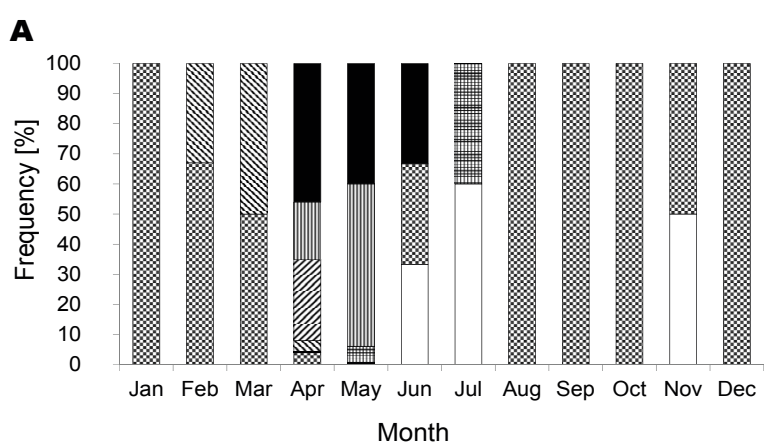

B

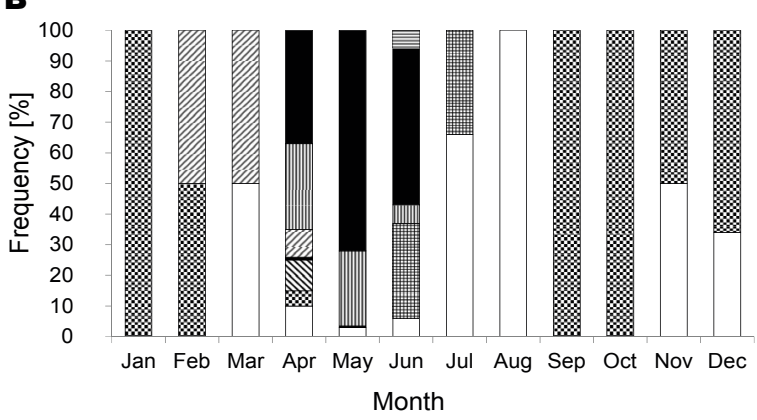

C

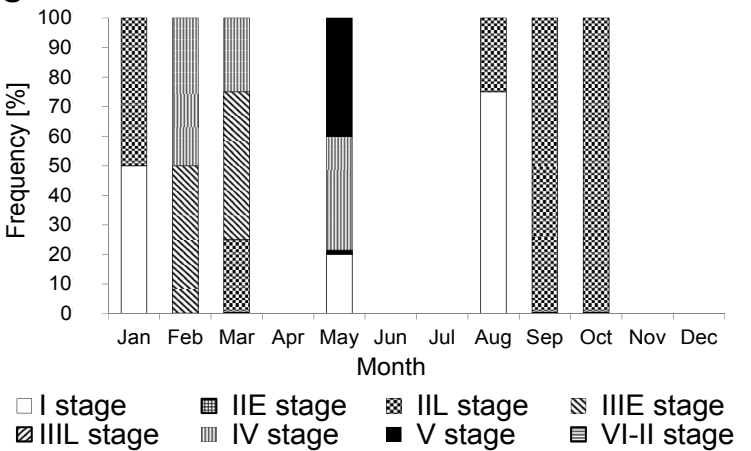

Fig. 7. Percentage contribution of the number of white bream, Blicca bjoerkna, males with gonads at particular stage of maturity in individual months of the calendar year from the three aquatic environments: Oder River (A), Lake Dąbie (B), warm-water canal (C)
Kestemont 1996). According to Rinchard and Kestemont (1996), the long spawning period and low temperatures in the autumn cause delays in the growth of oocytes in vitellogenesis of white bream. According to these authors, cyprinids that spawn in portions are characterized by a long rest period of gonads. Kopiejewska and Kozłowski (2007) also reported that the vitellogenesis in white bream gonads starts in the spring. These changes are visible based on the gradual increase in GSI and the increasing diameter of the largest oocytes. In most white bream females, vitellogenesis occurs in the spring (Trâpicyna 1975, Kopiejewska 1996, Kopiejewska and Kozłowski 2007). The presence of oocytes of trophoplasmatic growth in the autumn and winter may indicate high adaptive abilities of the species (Kopiejewska and Kozłowski 2007). Prior to the spawning period, in the gonads of the analysed white bream females, the variability of the pool of younger oocytes decreased, which was also observed by other authors (Kopiejewska and Kozłowski 2007, Rinchard and Kestemont 1996).

The size of oocytes at the different stages of development was similar to reported for the white bream from the Meuse River (Rinchard and Kestemont 1996), and the diameter of the most developed oocytes was smaller than that reported by Lefler (2010) (Table 4). The smaller size of oocytes in completed vitellogenesis in the females from the warm-water canal may be a result of the influence of temperature on the endocrine system and the rate of vitellogenin uptake into the oocyte (Tyler and Sumpter 1996).

The stages of reproductive cycle of cyprinid fish, including white bream, have been determined mostly in females (Kopiejewska 1996, Rinchard and Kestemont 1996, Kopiejewska and Kozłowski 2007, Lefler et al. 2008). No histological studies on the sexual cycle of the testis have been published. The male gonads of the investigated white bream during winter were at stage II, with some individuals starting meiosis as early as in February. In other cyprinids, gonads enter stage III earlier, even in the autumn (Mattheeuws et al. 1981, Billard 1986, Domagała et al. 2015). Another feature of the cycle was the quick cleaning of the seminal tubules from spermatozoa not expelled during mating.

Oocyte diameter $[\mu \mathrm{m}]$ of while bream, Blicca bjoerkna, at different stages of gonad maturity

Table 4 in different study areas

\begin{tabular}{lccc}
\hline \multirow{2}{*}{\multicolumn{1}{c}{ Study area and reference }} & \multicolumn{2}{c}{ Gonad maturity stage } \\
\cline { 2 - 4 } & Yolk 1 & Yolk 2 & Maturation \\
\hline Meuse River (Rinchard and Kestemont 1996) & $300-450$ & $550-1100$ & $750-1150$ \\
Lake Kortowskie (Kopiejewska and Kozłowski 2007) & - & - & $565-1285$ \\
Danube River (Lefler 2010) & - & - & 1500 \\
Lake Balaton (Lefler 2010) & - & $512-1117$ & $899-1057$ \\
Oder River (this paper) & $351-492$ & $529-1176$ & $967-1232$ \\
Lake Dąbie (this paper) & $347-507$ & $495-1128$ & $916-1186$ \\
Warm-water canal (this paper) & $295-478$ & & \\
\hline
\end{tabular}

Yolk 1 = oocytes are full of yolk vesicles, Yolk 2 = oocytes accumulate yolk globules and yolk vesicles. 
The analysed white bream females from all sites had the highest GSI (above 20) before and during spawning. The white bream specimens of the Meuse River had the highest GSI (14.5) just before spawning (Rinchard and Kestemont 1996), while those from Lake Sapanca had GSI slightly above 15 (Okgerman et al. 2012). In the spawning season, the GSI values of the investigated fish decreased systematically, which is related to depositing consecutive portions of eggs and has also been observed in white bream specimens from other locations (Rinchard and Kestemont 1996). According to our observations, the following group is ready for laying eggs after approx. 3 weeks. Taking into account gonad weight, GSI and the histological structure of gonads, it seems that the investigated white bream specimens deposit at least 2 portions of eggs in one season. In the analysed fish, the period of gonad recovery after spawning lasted a few weeks in July, similarly as in the fish of the same species in the Danube, Lake Balaton, and the Meuse River (Rinchard and Kestemont 1996, Lefler 2010). The repeated rapid increase in GSI starting from August was a result of an intense growth of oocytes, which in turn was a result of nutrient accumulation in early vitellogenesis. This process was also described by Lefler (2010), who demonstrated that high GSI values in white bream specimens from the Danube in August (3.8) are a result of oocyte growth as an effect of increasing progesterone levels. The completion of exogenous vitellogenesis in white bream occurred before spawning and the vitellogenic activity of the liver decreased during spawning. This phenomenon is contrary to that observed in other multispawner cyprinid species, e.g., Alburnus alburnus (Linnaeus, 1758) (see Rinchard and Kestemont 2003).

In the studied white bream males from the Oder River, the highest GSI values were those recorded at the beginning of reproductive season, similarly as in the white bream investigated by Okgerman et al. (2012). The maximum GSI observed by these authors was 10.7 . In our study, the mean value of the index was 7.1, while it reached 11.3 in individual animals.

In Poland white bream spawning occurs in water at 9.6-19. $4^{\circ} \mathrm{C}$ but the temperature preferred by this species is $20-24^{\circ} \mathrm{C}$ (Tadajewska 2000). In Lake Sapanca, breeding takes place at $13.7-28.5^{\circ} \mathrm{C}$ (Okgerman et al. 2012). According to Spivak (1987), in the Kahovka Reservoir, spawning of white bream occurs at the temperature of $12-23^{\circ} \mathrm{C}$. The second portion of eggs is laid in July at $18-29^{\circ} \mathrm{C}$ (Lefler 2010). White bream tolerates a wide range of temperature for spawning. Moreover, the larvae of white bream are able to survive at higher temperature than those of other cyprinids (Matondo et al. 2007). Therefore, the species was able to adapt to the environment of warmed water of the studied warm-water canal and proceed with spawning. Spawning in the warm-water canal began one month earlier (April) than in local waters of ambient temperature, while the males produced spermatozoa as early as in February (two months earlier). A similar offset in the sexual cycle has been observed in roach, Rutilus rutilus (Linnaeus, 1758), from the Meuse
River, where water temperature is increased (by a mean of $+3^{\circ} \mathrm{C}$ ) by water discharged from the Tihange Nuclear Power Plant (Mattheeuws et al. 1981). In tench, Tinca tinca (Linnaeus, 1758), kept in artificially heated water (by $6^{\circ} \mathrm{C}$ exceeding the ambient temperature), spermatogenesis began earlier too and the spawning period was considerably longer (by approx. 2 months) (Breton et al. 1980). During the presently reported study, in the hottest months of the year, no mature white bream were caught in the warm-water canal. Perhaps in that period, adult individuals moved to the waters below that site. Therefore, it is difficult to determine the date of the completion of spawning. An additional indicator of successful spawning in the warm-water canal is the large abundance of juvenile individuals of this species observed near the shore of a small bay inside the canal. White bream juveniles of a total length in the range of $5.5-8.0 \mathrm{~cm}, 4.0-8.0 \mathrm{~cm}$, and 5.5-7.0 cm were caught at the end of April, end of May, and at the beginning of July, respectively. The size of the youngest bream indicate that breeding took place at the beginning of April and the latest occurred at the end of June.

White bream is a common species in the lower Oder River. Spawning at that site occurs from early May to early July. The habitat of the warm-water canal, into which warm water from a power plant is discharged, is attractive to white bream, although hydrological features such as fast current and substantial depth of water limited the presence of the fish and their intensity of reproduction. No anomalies or disorders of oogenesis and spermatogenesis were found in the Canal. In that location, spawning of white bream occurs earlier than in the neighbouring thermally unaffected bodies of water. In the perspective of climate warming (Souchon and Tissot 2012), it may be expected that white bream will be able to maintain its status of a common species in the open waters of central Europe, since in waters with elevated temperature, its gametogenesis occurs without problems and the fish exhibit a typical pace of growth depending on the temperature.

\section{REFERENCES}

Alavi S.M.H., Cosson J. 2005. Sperm motility in fishes. I. Effects of temperature and $\mathrm{pH}$ : A review. Cell Biology International 29 (2): 101-110.

DOI: 10.1016/j.cellbi.2004.11.021

Barthelmes D. 1983. Effects of eutrophication and fisheries management on fish faunas of cyprinid lakes. Roczniki Nauk Rolniczych H 100 (3): 31-44.

Berg L.S. 1949. Ryby presnyh vod SSSR i sopredel'nyh stran. [Fishes of fresh waters of the USSR and adjacent countries.] Part 2. Izdatel'stvo Akademii Nauk SSSR, Moskva-Leningrad, USSR. [In Russian.]

Billard R. 1986. Spermatogenesis and spermatology of some teleost fish species. Reproduction Nutrition Développement 26 (4): 877-920.

DOI: $10.1051 / \mathrm{rnd}: 19860601$

Breton B., Horoszewicz L., Billard R., Bieniarz K. 1980. Temperature and reproduction in tench: Effect of a rise in the annual temperature regime on gonadotropin lev- 
el, gametogenesis and spawning. I. The male. Reproduction Nutrition Développement 20 (1A): 105-118. DOI: $10.1051 /$ rnd:19800106

Brett J.R. 1979. Environmental factors and growth. Pp. 599-675. In: Hoar W.S., Randall D.J., Brett J.R. (eds.) Fish physiology. Vol. 8. Bioenergetics and growth. Academic Press, NewYork, NY, USA.

Brylińska M., Żbikowska L. 1997. Ecology, growth and fecundity of a reproducing population of silver bream, Blicca bjoerkna, from a lowland river reservoir. Folia Zoologica 46 (4): 353-366.

Domagała J., Dziewulska K., Pilecka-Rapacz M. 2015. Annual cycle of gonad development in bream males (Abramis brama L.) from lower Oder River sections differing in the influence of cooling water. Pp. 182-183. In: The 5th International Workshop on the Biology of Fish Gametes, 7-11 September 2015, Ancona, Italy.

Domagała J., Kirczuk L., Pilecka-Rapacz M. 2013. Annual development cycle of gonads of Eurasian ruffe (Gymnocephalus cernuus L.) females from lower Odra River sections differing in the influence of cooling water. Journal of Freshwater Ecology 28 (3): 423-437. DOI: $10.1080 / 02705060.2013 .777855$

Domagała J., Kirczuk L., Pilecka-Rapacz M. 2015. Annual development cycle of gonads of bream (Abramis brama L. 1758) females from lower Oder river sections influenced differently by the heated effluents from a power station. Journal of Applied Ichthyology 31 (Suppl. 1): 41-48. DOI: $10.1111 /$ jai.12723

Domagała J., Kondratowicz A. 2005. Porównanie wybranych wskaźników fizyko-chemicznych wód kanału doprowadzającego i odprowadzającego Elektrowni Dolna Odra w latach 2000-2002. ["Comparison of selected physical and chemical indicators of water in inflowing and outflowing channels of Dolna Odra power plant in 2000-2002.”] Zeszyty Naukowe Wydziału Budownictwa i Inżynierii Środowiska [Politechnika Koszalińska.] Seria: Inżynieria Środowiska 22: 741750. [In Polish.]

Domagała J., Pilecka-Rapacz M. 2007. Charakterystyka wód pochłodniczych Elektrowni Dolna Odra w latach 2004-2006. ["The profile of post cooling water from Dolna Odra Power Plant 2004-2006.”]. Zeszyty Naukowe Wydziału Budownictwa i Inżynierii Środowiska [Politechnika Koszalińska.] Seria: Inżynieria Środowiska 23: 751-760. [In Polish.]

Hacker R. 1979. Fishes and fishery in Neusiedlersee. Pp. 423-438. In: Löffler H. (ed.) Neusiedlersee: The limnology of a shallow lake in Central Europe. Dr. W. Junk Publishers, The Hague, Boston, London. DOI: $10.1007 / 978-94-009-9168-2$

Herzig A., Winkler H. 1986. The influence of temperature on the embryonic development of three cyprinid fishes, Abramis brama, Chalcalburnus chalcoides mento and Vimba vimba. Journal of Fish Biology 28 (2): 171-181.

DOI: $10.1111 / \mathrm{j} .1095-8649.1986 . t b 05155 . x$
Hunter J.R., Goldberg S.R. 1980. Spawning incidence and batch fecundity in northern anchovy, Engraulis mordax. Fishery Bulletin 77 (3): 641-652.

Jafri S.I.H. 1989. The effects of photoperiod and temperature manipulation on reproduction in the roach Rutilus rutilus (L.) (Teleostei). Pakistan Journal of Zoology 21 (4): 289-299.

Janáč M., Ondračková M., Jurajda P., Valová Z., Reichard M. 2010. Flood duration determines the reproduction success of fish in artificial oxbows in a floodplain of a potamal river. 1990. Ecology of Freshwater Fish 19 (4): 644-655. DOI: $10.1111 / \mathrm{j} .1600-0633.2010 .00449 . x$

Jobling M. 2003. The thermal growth coefficient (TGC) model of fish growth: A cautionary note. Aquaculture Research 34 (7): 581-584. DOI: $10.1046 /$ j.1365-2109.2003.00859.x

Koli L. 1990. Suomen kalat. [Fishes of Finland]. Werner Söderström Osakeyhtiö. Helsinki. [In Finnish.]

Kompowski A., Neja Z. 1999. The Międzyodrze ichthyofauna as caught by various gear. Baltic Coastal Zone 1999 (3): 103-112.

Kopiejewska W. 1996. Germ line of white bream, Blicca bjoerkna (L.) females in Włocławek Reservoir. Acta Ichthyologica et Piscatoria 26: (2): 35-47.

Kopiejewska W., Kozłowski J. 2007. Development structure of ovaries in female white bream, Abramis bjoerkna from Lake Kortowskie in north-eastern Poland. Folia Zoologica 56 (1): 90-96.

Lahnsteiner F., Mansour N. 2012. The effect of temperature on sperm motility and enzymatic activity in brown trout Salmo trutta, burbot Lota lota and grayling Thymallus thymallus. Journal of Fish Biology 81 (1): 197-209. DOI: $10.1111 /$ j.1095-8649.2012.03323.x

Lammens E.H.R.R., Frank-Landman A., McGillavry P.J., Vlink B. 1992. The role of predation and competition in determining the distribution of common bream, roach and white bream in Dutch eutrophic lakes. Environmental Biology of Fishes 33 (1-2): 195-205.

DOI: $10.1007 / \mathrm{BF} 00002564$

Lefler K.K. 2010. Ovarian cycle of fish species of natural waters. Thesis of Ph.D. dissertation. Szent István University. Gödöllö, Hungary.

Lefler K.K., Hegyi Á., Baska F., Gál J., Horváth Á., Urbányi B., Szabó T. 2008. Comparison of ovarian cycles of Hungarian riverine fish species representing different spawning strategies. Czech Journal of Animal Science 53 (10): 441-452.

Leuven R.S.E.W., Wendelaar Bonga S.E., Oyen F.G.F., Hagemeijer W. 1987. Effects of acid stress on the distribution and reproduction success of freshwater fish in Dutch soft waters. Annales de la Société royale zoologique de Belgique 117: 231-242.

Luksjene D., Sandström O. 1994. Reproductive disturbance in a roach (Rutilus rutilus) population affected by cooling water discharge. Journal of Fish Biology 45 (4): 613-625. DOI: $10.1111 /$ j.1095-8649.1994.tb00928.x 
Lukšjenė D., Sandström O., Lounasheimo L., Andersson J. 2000. The effects of thermal effluent exposure on the gametogenesis of female fish. Journal of Fish Biology 56 (1): 37-50.

DOI: $10.1111 /$ j.1095-8649.2000.tb02085.x

Lukšjenė D., Svedäng H. 1997. A review on fish reproduction with special reference to temperature anomalies. Fiskeriverket, Kustlaboratoriet, Öregrund, Sweden.

Mann R.H.K., Mills C.A., Crisp D.T. 1984. Geographical variation in the life-history tactics of some species of fresh-water fish. Pp. 171-186. In: Potts G.W., Wootton R.J. (eds.) Fish reproduction: Strategies and tactics. Academic Press, London, UK.

Matondo B.N., Ovidio M., Poncin P., Kakesa T.A., Wamuini L.S. Philippart J.-C. 2007. Hybridization success of three common European cyprinid species, Rutilus rutilus, Blicca bjoerkna and Abramis brama and larval resistance to stress tests. Fisheries Science 73 (5): 1137-1146.

DOI: $10.1111 / \mathrm{j} .1444-2906.2007 .01445 . x$

Mattheeuws A., Genin M., Detollenaere A., Micha J.-C. 1981. Etude de la reproduction du gardon (Rutilus rutilus) et des effets d'une élévation provoquée de la température en Meuse sur cette reproduction. Hydrobiology 85 (3): 271-282.

DOI: $10.1007 / \mathrm{BF} 00017615$

Molls F. 1999. New insights into the migration and habitat use by bream and white bream in the floodplain of the River Rhine. Journal of Fish Biology 55 (6): 1187-1200.

DOI: 10.1111/j.1095-8649.1999.tb02069.x

Okgerman H.C., Elp M., Atasagun S. 2012. The growth and reproduction of white bream (Blicca bjoerkna L. 1758) in an oligo-mesotrophic lake in northwest Anatolia (Sapanca, Turkey). Turkish Journal of Biology 36 (1): 125-134.

DOI: $10.3906 /$ biy-1012-157

Olin M. 2009. Fish communities, biomanipulation and experimental gillnetting: Fish communities in south-Finnish lakes and their responses to biomanipulation assessed by experimental gillnetting. VDM Verlag Dr. Müller, Saarbrücken, Germany.

Persson L., Diehl S., Johansson L., Andersson G., Hamrin S.F. 1991. Shifts in fish communities along the productivity gradient of temperate lakes - patterns and the importance of size-structured interactions. Journal of Fish Biology 38 (2): 281-293.

DOI: 10.1111/j.1095-8649.1991.tb03114.x

Poncin P., Termol C., Matondo B.N., Philippart J.-C., Kestemont P. 2010. Behavioural study of polyandrous spawning in Blicca bjoerkna under a controlled environment. Folia Zoologica 59 (3): 257-266.

Rinchard J., Kestemont P. 1996. Comparative study of reproductive biology in single- and multispawner cyprinid fish. I. Morphological and histological features. Journal of Fish Biology 49 (5): 883-894. DOI: $10.1111 /$ j.1095-8649.1996.tb00087.x
Rinchard J., Kestemont P. 2003. Liver changes related to oocyte growth in roach, a single spawner fish, and in bleak and white bream, two multiple spawner fish. International Review of Hydrobiology 88 (1): 68-76. DOI: 10.1002/iroh.200390006

Sakun O.F., Buckaâ N.A. [Butskaya N.A.] 1963. Opredelenie stadij zrelosti i izučenie polovyh ciklov ryb. [Determination of maturity stages and studies on sexual cycles of fishes.] Izdatel'stvo Rybnoe Hozâjstvo, Moskva, USSR. [In Russian.]

Sandström O., Neuman E., Thoresson G. 1995. Effect of temperature on life history variables in perch. Journal of Fish Biology 47 (4): 652-670.

DOI: $10.1111 /$ j.1095-8649.1995.tb01932.x

Souchon Y., Tissot L. 2012. Synthesis of thermal tolerances of the common freshwater fish species in large Western Europe rivers. Knowledge and Management of Aquatic Ecosystems 405: 03.

DOI: $10.1051 / \mathrm{kmae} / 2012008$

Specziár A., Tölg L., Bíró P. 1997. Feeding strategy and growth of cyprinids in the littoral zone of Lake Balaton. Journal of Fish Biology 51 (6): 1109-1124. DOI: $10.1111 /$ j.1095-8649.1997.tb01130.x

Spivak E.G. 1987. Osobennosti razmnoženiâ gustery Blicca bjoerkna (L.) v zalivah Kahovskogo vodohraniliŝa. [Reproduction of the white bream Blicca bjoerkna (L.) in Kahovsk Reservoir bays.] Voprosy Ihtiologii 27 (1): 101-105. [In Russian.]

Spratte S., Hartmann U. 1997. Fischartenkataster: Suswasserfische und Neunaugen in Schleswig-Holstein. Ministerium für landliche Raume, Landwirtschaft, Ernahrung und Tourismus, Kiel, Germany.

Tadajewska M. 2000. Krąp (Blicca bjoerkna L.). [White bream (Blicca bjoerkna L.).] Pp. 249-257. In: Brylińska M. (ed.) Ryby słodkowodne Polski. [Freshwater fish of Poland.] PWN, Warszawa. [In Polish.]

Tadajewska M., Żbikowski J., Laskowski M. 1997. Diagnostic features of scales of bream Abramis brama (L.) and white bream Blicca bjoerkna (L.). Acta Ichthyologica et Piscatoria 27 (1): 5-26.

Tátrai I., Mátyás K., Korponai J., Paulovits G., Pomogyi P., Pekár F. 2003. Management of fish communities and its impacts on the lower trophic levels in shallow ecosystems in Hungary. Hydrobiology 506 (1-3): 489-496.

DOI: 10.1023/B:HYDR.0000008616.52608.51

Trâpicyna L.N. [Tryapitsyna L.N.] 1975. Èkologiâ krasnoperki i gustery del'ty Volgi $v$ usloviâh zaregulirovannogo stoka. [Ecology of rudd and white bream from the Volga river delta under conditions of regulated flow.] Izdatel'stvo Nauka, Moskva, USSR. [In Russian.]

Tyler C.R., Sumpter J.P. 1996. Oocyte growth and development in teleosts. Reviews in Fish Biology and Fisheries 6 (3): 287-318.

DOI: $10.1007 / \mathrm{BF} 00122584$

Wallace R.A., Selman K. 1981. Cellular and dynamic aspects of oocyte growth in teleosts. American Zoologist 21 (2): 325-343.

DOI: $10.1093 / \mathrm{icb} / 21.2 .325$ 
Wiśniewolski W., Wołos A., Borzęcka I. 2009. Assessing angling catches in dam reservoirs on the example of Zegrze Dam Reservoir. Archives of Polish Fisheries 17 (4): 211-220.

DOI: $10.2478 / \mathrm{v} 10086-009-0013-0$

Yılmaz S., Yazıcıoğlu O., Erbaşaran M., Esen S., Zengin M., Polat N. 2012. Length-weight relationship and relative condition factor of white bream, Blicca bjoerkna (L., 1758), from Lake Ladik, Turkey. Journal of the Black Sea/Mediterranean Environment 18 (3): 380-387.
Yılmaz S., Yazıcıoğlu O., Yazıcı R., Polat N. 2015. Age, growth and reproductive period of white bream, Blicca bjoerkna (L., 1758) in Lake Ladik, Turkey. Limnofish 1 (1): $9-18$.

Received: 16 February 2015

Accepted: 4 August 2015

Published electronically: 30 September 2015 